\title{
キヌア澱粉の諸性質と糊化特性
}

\author{
大迫早苗*1*2 ・ 永島伸浩*3 $・$ 石田 裕 ${ }^{* 4} \cdot$ 岡田早苗*1
}

$\left({ }^{* 1}\right.$ 東京農業大学大学院農学研究科, ${ }^{* 2}$ 相模女子大学短期大学部, ${ }^{* 3}$ 武蔵丘短期大学,

*4 東京農業大学短期大学部)

\section{Characterization of Quinoa Starch and Its Pasting Properties}

\author{
Sanae Osako* ${ }^{* 2}$, Nobuhiro Nagasima* ${ }^{* 3}$, Hirosi Ishida** , Sanae Okada*1 \\ *1 Department of Environmental Symbiotic Biological Science, Graduate School of Agriculture, Tokyo Uni- \\ versity of Agriculture, 1-1-1 Sakuragaoka Setagaya-ku Tokyo, 156-8502 \\ ${ }^{*}$ Sagami Women's University Junior College, 2-1 - 1 Bunkyou Sagamihara-shi Kanagawa, 228-8533 \\ ${ }^{*}$ Musashigaoka Junior College, 111- 1 Minamiyoshimi Yoshimi-chou Saitama, 355-0154 \\ ${ }^{* 4}$ Tokyo University of Agriculture Junior College, 1-1 - 1 Sakuragaoka Setagaya-ku, Tokyo, 156-8502

$$
\begin{aligned}
& \text { *1*4 } \bar{\top} 156 \text {-8502 東京都世田谷区桜丘 1-1-1 } \\
& \text { *2 } 7228-8533 \text { 神奈川県相模原市文京 2-1-1 } \\
& { }^{* 3} \text { \% 355-0154 埼玉県比企郡吉見町南吉見 111- } 1
\end{aligned}
$$

The use of cereals is being reexamined as people become more health conscious. When compared to grass cereals, quinoa is richer in proteins, lipids, vitamins, minerals and dietary fibers. Quinoa has also been investigated as a food that prevents lifestyle diseases, and is emerging as a promising new food material with health-promoting functions. In the present study, quinoa starch was prepared from quinoa flour, and the basic characteristics of quinoa starch were compared to those of both rice and corn starches.

Quinoa starch was found to be smaller than both rice and corn starch. Scanning electron microscopy (SEM) showed that quinoa starch was much finer, and, in terms of particle-size distribution, the average particle-size for quinoa, rice and corn starches was 2.5, 4.3 and $9.8 \mu \mathrm{m}$, respectively. X-ray diffraction showed that, like rice and corn starches, quinoa starch exhibited a typical type A pattern for cereal starches. The amylose content, as assessed by amperometric titration, for quinoa, rice and corn starches was $18.7,12.7$ and $27.2 \%$, respectively. Photopastegraphy, differential scanning calorimetry (DSC) and Rapid Visco Analyzer (RVA) measurements showed that the gelatinization onset temperature was slightly higher than the RVA value for all three starches. When compared to rice and corn starches, the breakdown and setback values for quinoa starch were particularly lower and did not change much after cooling. Its specific curve indicates that quinoa starch is more resistant to senescence.

\section{I．緒言}

キヌアは, 南アメリカのエクアドル, ペルー, ボリビ

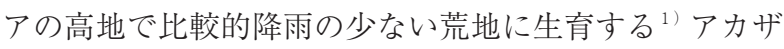
科に属する 1 年草の雑穀である。栽培されているキヌア (Chenopodium quinoa) はサワー種とレアル種があり，
日本でもレアル種でボリビア産キヌアを輸入し製品とし て供給されている ${ }^{1)}$ 。近年, 健康志向が高まり，雑穀の 利用が省みられている。その一つとしてキヌアは，イネ 科の穀類と比べ，たんぱく質，脂質，ビタミン，無機質， 食物繊維を多〈含む2３３４）ことから生活習慣病を予防す る食品として注目されている。また, アレルギー疾患用 
の代替食材 ${ }^{5)}$ や，健康機能性を持つ新しい食品素材とし て可能性が期待されている。小西ら ${ }^{1)}$ は通常は食さず廃 棄物として扱われているキノア（キヌア）の外皮にコレ ステロールの低下作用があることを報告しているが，食 品学的研究は希少である ${ }^{6)}{ }^{7)}$ 。著者らは, キヌア全粒粉 を添加したスポンジケーキやパン等8）9）の食味特性につ いて検討してきたが，キヌア全粒粉の添加率が $20 \%$ を超 えると形状も食味も小麦粉製品とは異なるものであった。 そこでキヌアの特性を明らかにするために，まずキヌア 澱粉を調製し, その糊化特性や澱粉の微細構造を明らか にし，地上系のコメおよびトウモロコシ澱粉と比較して どのような特性を持つのかを検討した。その結果，キヌ ア澱粉の一般的な諸性質および糊化過程について若干の 知見が得られたので報告する。

\section{II. 試料および実験方法}

1. 試料

1) キヌア澱粉

キヌア澱粉は，大日本明治製糖(株)（2008年ボリビア産） を用い常法 ${ }^{10)} に よ り$ 調製した。

\section{2 ) コメ澱粉}


した。

3）トウモロコシ澱粉

トウモロコシ澱粉は, 日本食品化工(株製のものを常 法 ${ }^{10)} に よ り$ 精製した。

なお，地上系の澱粉であるコメおよびトウモロコシ澱 粉は対照として用いた。

\section{2. 方法}

\section{1) 顕微鏡観察}

各試料は試料台に固定し，イオンスパッター装置（日 本電子(株) FC-1100型）により，金一パラジウムのコー ティングを施し, 走査型電子顕微鏡 (以下 SEM と略す) (日本電子(株)，JSM-T20型）で観察した。

\section{2 ）無機質の定量}

キヌア澱粉と粉砕したキヌア粒（以下キヌア全粒と略 す）は各 $1 \mathrm{~g}$ をそれぞれのルツボに秤取し，500～ $550^{\circ} \mathrm{C}$ で灰化し ${ }^{11)}$ ，塩酸処理後，原子吸光分析装置（日 立 A2000）で，カリウム，ナトリウム，カルシウム， マグネシウムを測定した。

\section{3) X 線回折図形}

各粉末試料は常法 ${ }^{12)}$ に準じて X 線回折装置 $(\mathrm{XRD}-$ 6100 島津社製）を用いて結晶図形を測定した。

\section{4 ) 粒径分布}

粒径分布の測定は Mutlisizer 3 (ベックマン・コール ター社製）によって行った。

5 ) 溶解度・膨潤力

貝沼ら ${ }^{13)}$ の方法に準じて，50，60，70，80，90 C の各 温度における溶解度・脵潤力を測定した。

6 ）ヨウ素親和力およびアミロース含量
高感度電流滴定装置 (平間理化研究所製, ATR-CU-I) を用い，福場ら ${ }^{14)}$ の方法に準じて澱粉のヨウ素親和力 を測定し，澱粉のアミロース含量を求めた。基準とす るアミロースは，市販の馬鈴薯アミロースを用いた。

7 ）フォトペーストグラフィー

貝沼ら ${ }^{15)}$ の方法に準じ, 澱粉 $0.05 \%$ （無水物換算）懸 濁液 $50 \mathrm{~mL}$ を試料とし，フォトペーストグラフ（平間 理化研究所製， ART- 3 ) を用い, $2{ }^{\circ} \mathrm{C} / \mathrm{min}$ で昇温 させながら，372nmにおける透過率の変化を40〜 $90^{\circ} \mathrm{C}$ まで測定した。

\section{8 ) 示差走査熱分析}

澱粉 $40 \mathrm{mg}$ （無水物換算）を $70 \mu \mathrm{L}$ 容の銀容器に $30 \%$ 濃 度になるように純水を加えて封入し, 示差走査熱量計 （セイコー電子工業製 SSC/5200型，以下 DSC と略す） を用いて, 20〜 $120^{\circ} \mathrm{C}$ の温度範囲で, 昇温速度 $2^{\circ} \mathrm{C} /$

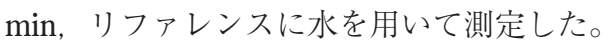

9 ) ビスコグラフィー

ラビットビスコアナライザー（Rapid visco analyser 以 後 RVA と略す：ニューポートサイエンテック社 RVA$3 \mathrm{D}$ 型）を用い，澱粉 $8 \%$ 濃度に調製し， $50^{\circ} \mathrm{C} て ゙ 1$ 分 間攪拌後，50 95まで $5{ }^{\circ} \mathrm{C} / \mathrm{min}$ で昇温し， $95^{\circ} \mathrm{C}$ で 2 分間恒温保持した後, $50^{\circ} \mathrm{C}$ まで昇温時と同一速度で降 温させ，粘度変化を測定した。

\section{III. 結果および考察}

\section{1. 走査型電子顕微鏡観察}

図 1 は, キヌア粒と各澱粉の内部組織像である。キ又
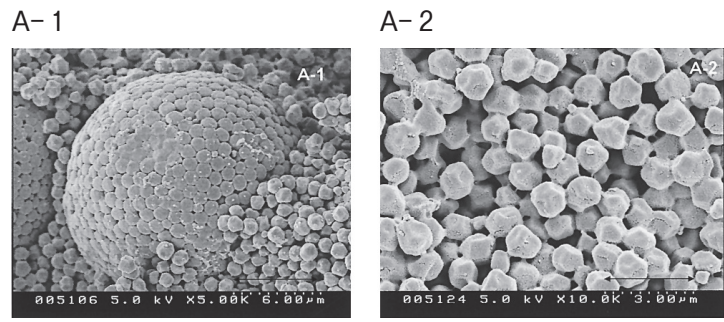

\section{B- 1}

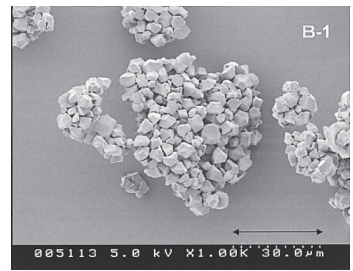

C-1


C-2

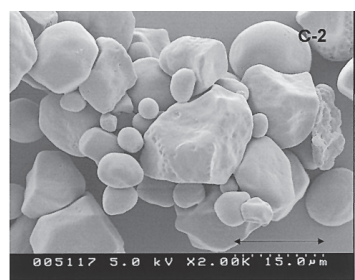

図 1 各澱粉の SEM 観察

A-1，A-2：キヌア澱粉，B-1，B-2 : コメ澱粉，C-1 C-2 : トゥモロコシ澱粉 
ア澱粉は，対照のトウモロコシ，コメに比べかなり小さ く細胞と細胞は密接し，複粒の形態であることが観察さ れた。

\section{2.ミネラル}

ミネラル含量の結果を図 2 に示した。キヌア全粒では ナトリウム $65 \mathrm{mg}$, カリウム $332 \mathrm{mg}$, カルシウム $126 \mathrm{mg}$, マグネシウム $40 \mathrm{mg}$ で, キヌア澱粉ではナトリウム $5 \mathrm{mg}$, カリウム $7 \mathrm{mg}$ ，カルシウム $105 \mathrm{mg}$ マグネシウム $28 \mathrm{mg}$ であった。澱粉での残存率はマグネシウムとカルシウム が高く，ナトリウムとカリウムの一価陽イオンの残存率 は低い傾向であった。小西ら ${ }^{1)}$ は, キヌア全粒のナトリ ウム $12 \mathrm{mg}$ ，カリウム $927 \mathrm{mg}$ ，カルシウム $149 \mathrm{mg}$ ，マグ ネシウム $250 \mathrm{mg}$ と報告しているが，本実験ではナトリ ウム以外は低い值であった。これは両者の育った環境条 件によるものであると考えられる。

\section{X線回折}

$\mathrm{X}$ 線回折の結果を図 3 に示した。澱粉の X 線回折図形 は $\mathrm{A} ， \mathrm{~B}$ および $\mathrm{C}$ 図形に分類される。トウモロコシ澱粉 に代表される $\mathrm{A}$ 型図形は穀類澱粉に一般的にみられ， ジャガイモ澱粉に代表される B 型図形は根系類の澱粉 に一般にみられ，その他は $\mathrm{A}$ 型と $\mathrm{B}$ 型が混在する $\mathrm{C}$ 型 に分類されている。 3 種類の澱粉は，第 1 環と第 $3 \mathrm{a}$ 環 が欠如し，第 4 環が $\mathrm{a}, \mathrm{b}$ に分かれて同程度に強く，第 6 $\mathrm{a}$ 環が強く存在する典型的な $\mathrm{A}$ 型図形を示し, これは小 西ら ${ }^{1)}$ の報告と同様の結果が得られた。

\section{4. 粒径分布}

粒径分布の結果を図 4 に示した。各澱粉の最多分布は, キヌア澱粉 $2.0 \mu \mathrm{m}$ ，コメ澱粉は $4.9 \mu \mathrm{m}$, トウモロコシ澱 粉は13. $28 \mu \mathrm{m}$ で, キヌアは他の 2 種類の澱粉よりも小

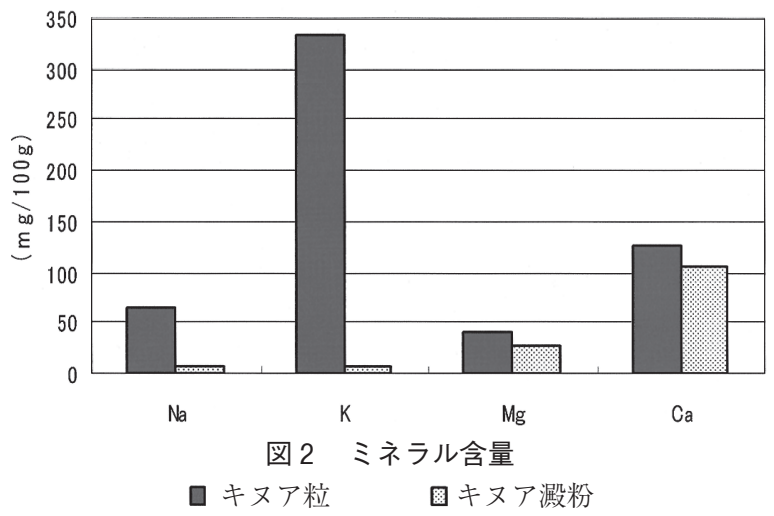

さかった。さらに平均粒径は, キヌアは $2.5 \mu \mathrm{m}$, コメは 4. $3 \mu \mathrm{m}$, トウモロコシは9. $8 \mu \mathrm{m}$ で，他の 2 種類の澱粉よ りかなり小さく, SEM 観察の結果と一致した。Ranhotra $^{16)}$ らはキヌア平均粒径を0.5〜 $2 \mu \mathrm{m}$ と報告してい るが, 本実験では近似值を示した。

\section{5 . 溶解度・膨潤力}

種々の温度で測定した澱粉粒の溶解度を図 5-1に, 膨潤力を図 5-2 に示した。各澱粉の溶解度は $70^{\circ} \mathrm{C} く ら$

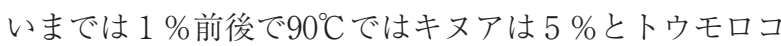
シに近い值を示した。膨潤力は, 各澱粉とも50年より緩 やかな上昇曲線を示した。

\section{6. 澱粉のアミロース含量}

電流滴定法によるアミロース含量はキヌアが $18.7 \%$,

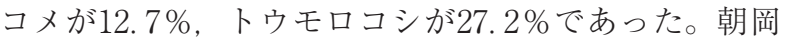
ら ${ }^{17)}$ の報告ではコメは8.3〜30.8\%の間に分布しており, 同一種属間のばらつきの範囲と考えられ，キヌアについ ても同様に環境条件等でのばらつきと考えられ，数值の 信頼性はあると考えられる。今後, キヌア澱粉をイソア ミラーゼで枝切りする方法を行い, 澱粉の微細な構造に ついて検討を図りたいと考える。

\section{7. 糊化過程}

澱粉の希薄懸濁液濃度の0.05\%および0.1\%でのフォ

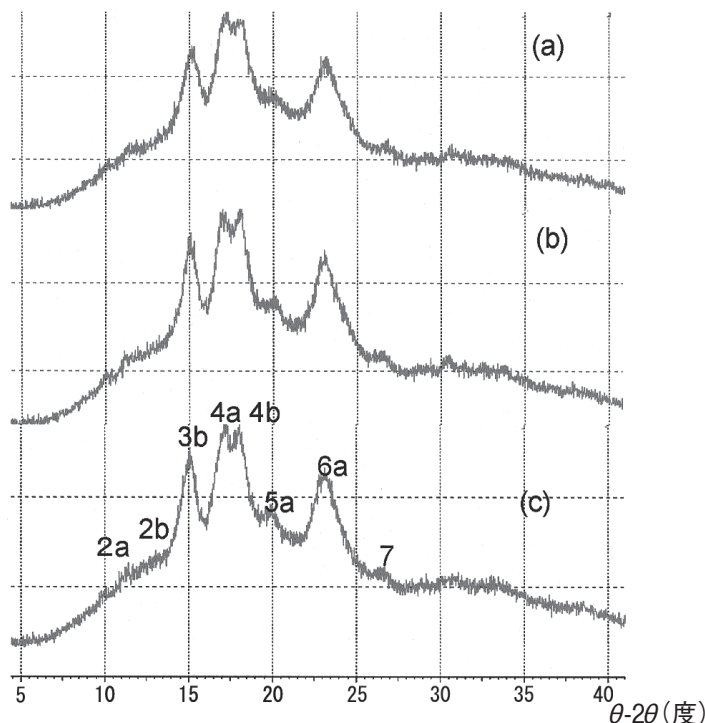

図 3 各澱粉の X 線回折図形

（a）キヌア澱粉（b）コメ澱粉（c）トウモロコシ澱粉



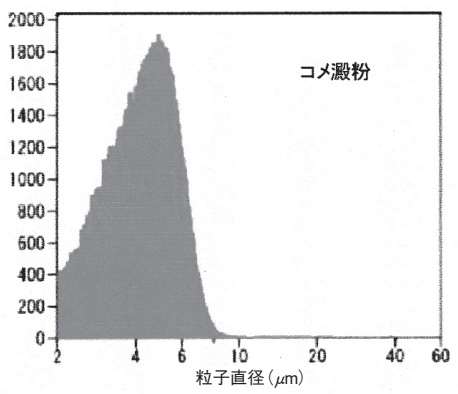



図4 各澱粉の粒径分布 




図 5-1 各澱粉における溶解度

ーコメーートウモロコシーーキヌア

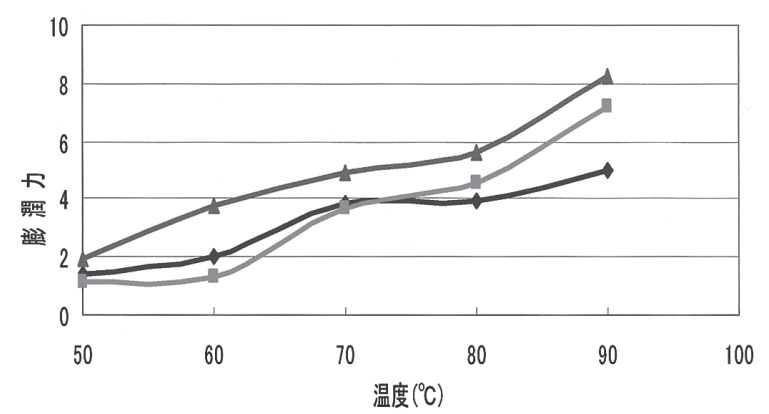

図 5-2 各澱粉における膨潤力

ナコメーートウモロコシ ーキキア
トペーストグラフを図 6 に示した。透過度変化点より求 めた糊化開始温度は, キヌアは $0.05 \%$ 濃度では $53^{\circ} \mathrm{C}$,

0. $1 \%$ では $58^{\circ} \mathrm{C}$ ，コメが $0.05 \%$ で $55^{\circ} \mathrm{C} ， 0.1 \%$ で $62^{\circ} \mathrm{C}$ ， 卜 ウモロコシが $0.1 \%$ で $68^{\circ} \mathrm{C}$ であった。キヌアは他の澱粉 よりも糊化開始温度が低く，コメ，トウモロコシのよう な温度上昇にともなう曲線は見られなかった。キ又ア澱 粉はコメ, トゥモロコシ澱粉に比べ透過率の低い澱粉で あることが考察された。

\section{8. 示差走査熱分析}

各澱粉（30\%濃度）をDSCにより測定した糊化特性 值を表 1 に示した。澱粉の吸熱開始温度（To），ピーク 温度 $(\mathrm{Tp})$, 終了温度 $(\mathrm{Tc})$ および吸熱エンタルピー（ H）を求めた。表 1 に示すようにキ又アは，コメ，トウ モロコシに比べ, フォトペーストの結果と同じくTo,

$\mathrm{Tp}, \mathrm{Tc}$ は低く, $\Delta \mathrm{H}$ も小さい傾向であった。これは小 西ら ${ }^{1)}$ の報告と同様の傾向を示したが，トウモロコシは

表 1 各澱粉（30\%）の吸熱温度およびエネルギー

\begin{tabular}{l|c|c|c|c}
\hline & $\begin{array}{c}\text { 吸熱開始温度 } \\
\left({ }^{(} \mathrm{C}\right)\end{array}$ & $\begin{array}{c}\mathrm{To}) \\
\text { 熱ピーク温度 }(\mathrm{Tp})\end{array}$ & $\begin{array}{c}\text { 吸熱終了温度 }(\mathrm{Tc}) \\
\left({ }^{(} \mathrm{C}\right)\end{array}$ & $\begin{array}{c}\Delta \mathrm{H} \text { 吸熱エンタルピー } \\
(\mathrm{mJ} / \mathrm{mg})\end{array}$ \\
\hline キヌア & 55.7 & 62.3 & 71 & 6.9 \\
\hline コメ & 62.1 & 69.4 & 82.3 & 8.4 \\
\hline トゥモロコシ & 69.5 & 73.4 & 81 & 9.7 \\
\hline
\end{tabular}

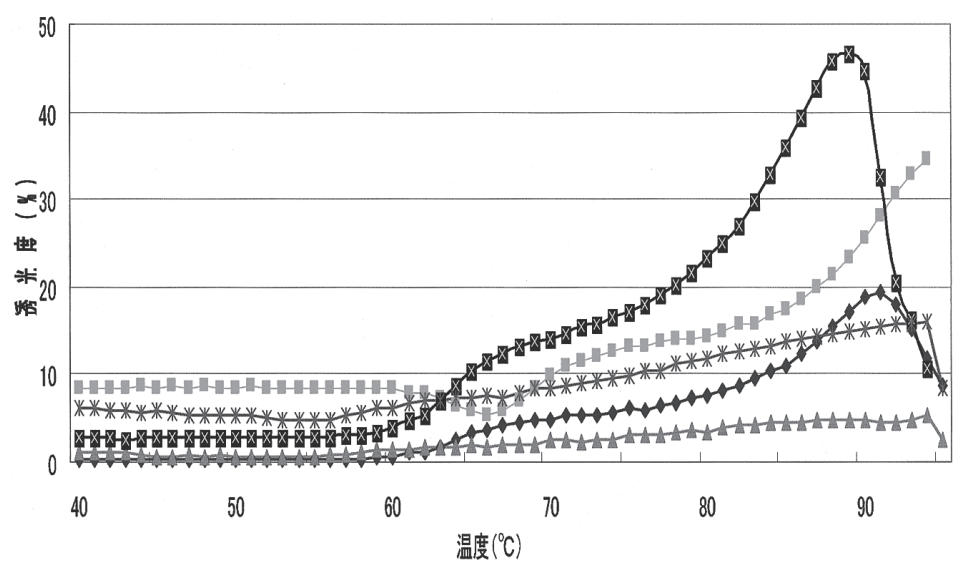

図 6 各澱粉のフォトペーストグラム

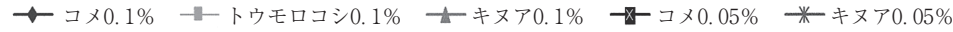

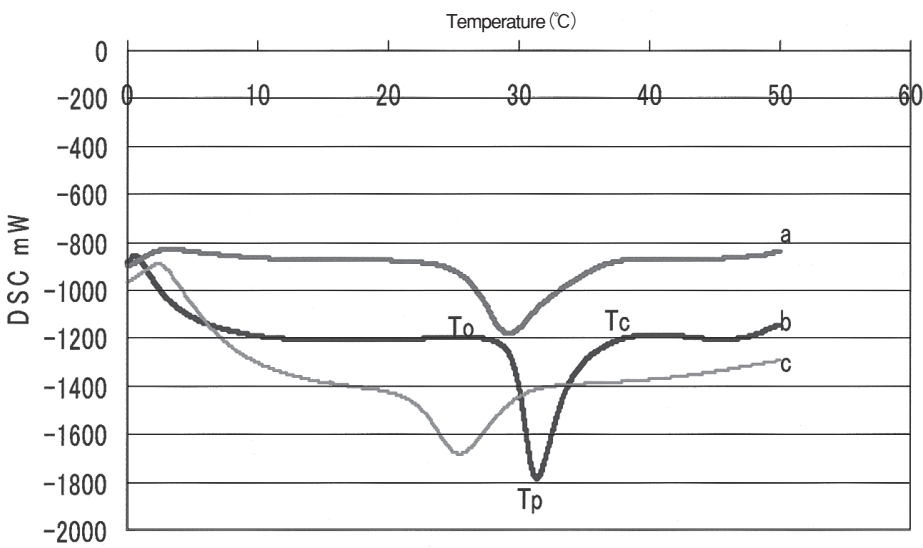

図 7 各澱粉における示差走査熱量分析

$\mathrm{a}$ : コメ $\mathrm{b}$ ：トウモロコシ $\quad \mathrm{c}$ ：キヌア

To: 吸熱開始温度, Tp: 吸熱ピーク温度, Tc: 吸熱終了温度 


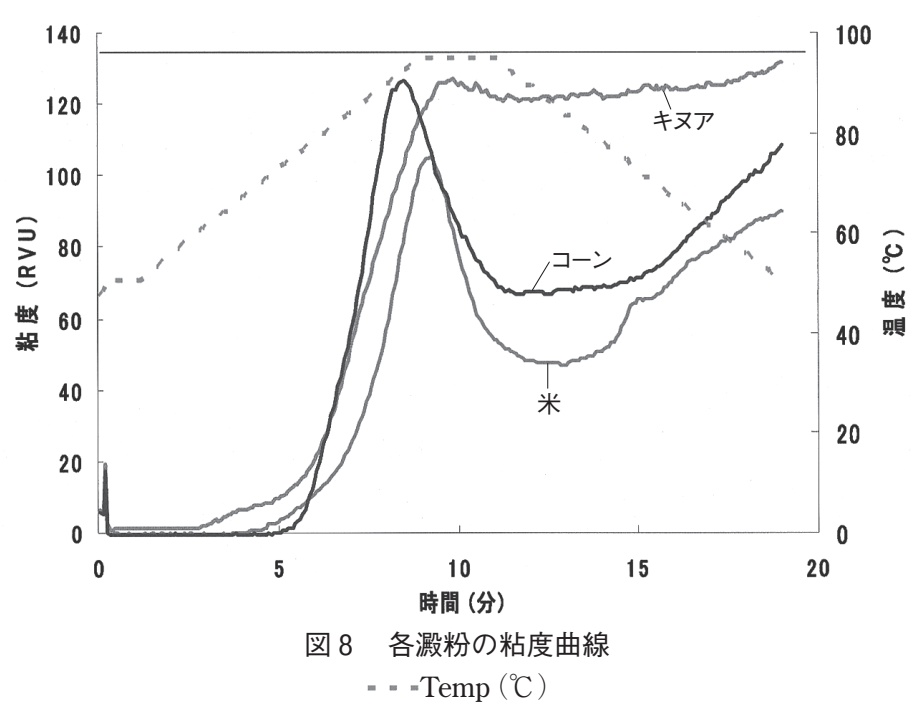

やや高い值であった。これは生育環境により若干のばら つきが見られたと考えられる。図 7 より糊化時の吸熱開 始温度から吸熱終了温度までの温度幅（To〜 T c ）は, キヌアが $15.3^{\circ} \mathrm{C}$, コメが $20.2^{\circ} \mathrm{C}$, トウモロコシが $11.5^{\circ} \mathrm{C}$, トウモロコシが 3 種類の澱粉の中でシャープなピークを 示した。糊化時の吸熱エネルギー量 $(\Delta \mathrm{H})$ はキヌアが $6.9 \mathrm{~mJ} / \mathrm{mg}$, コメが $8.4 \mathrm{~mJ} / \mathrm{mg}$, トウモロコシが $9.7 \mathrm{~mJ} /$ $\mathrm{mg}$ で糊化に必要な吸熱エネルギーはキヌアが最も少な く，糊化しやすい澱粉であることが推察された。

9. ビスコブラム

RVA における濃度 8 \%の粘度曲線を図 8 に示した。 粘度上昇開始温度は, キヌアが $63.0^{\circ} \mathrm{C}$, コメが $70.3^{\circ} \mathrm{C}$, トウモロコシが $72.5^{\circ} \mathrm{C}$ であった。一般にビスコグラムの 粘度上昇開始温度はDSCのピーク温度に相関すると言 われているが, 本実験でも同様の傾向が認められた。最 高粘度と最低粘度の差であるブレイクダウンは, キヌア 6. 3RVU, コメ62.5RVU, トウモロコシ61.2RVU, 最低 粘度と冷却することによる増加する最終粘度の差である セットバックはキヌア10RVU，コメ42.5RVU，トウモ ロコシ42.5RVUであった。キヌア澱粉はブレイクダウン, セットバックがコメ，トウモロコシ澱粉よりかなり低い 值を示し，これはキヌア澱粉の特異的な粘度挙動を示唆 しているものと推察される。

澱粉の場合, 粘度曲線の最高粘度は, 澱粉粒子の膨潤 の程度と相関関係があるといわれ ${ }^{18)}$ ，粒の膨潤とこれに よる抵抗が最大となる粘度である。ブレークダウンは, 膨潤粒子の崩壊に伴う粘度の減少である ${ }^{19)}$ 。セットバッ クは加熱後一定の速度で泠却していくと一度糊化した澱 粉分子間で若干水素結合が形成され，粘度が再上昇する。 この值を老化度の指数とし，值が大きほど老化しやすい ことを表している ${ }^{16)}$ ○ヌアはコメ, トウモロコシに比べ, 老化しにくい澱粉であると考えられ，キヌア澱粉の特徴 と思われる。

\section{V. 要 約}

キヌアの特性を明らかにするためにキヌア粒から澱粉 を調製し，キヌア澱粉の基本的特性についてコメおよび トウモロコシ澱粉と比較検討し，以下の結果を得た。

1. SEM 観察よりキヌア澱粉が対照のコメ，トウモロ コシよりかなり小さいことが観察され，このことは, 粒径分布の平均粒径でキヌアは $2.5 \mu \mathrm{m}$ ，コメは $4.3 \mu \mathrm{m}$, トウモロコシは $9.8 \mu \mathrm{m}$ で, 他の 2 種類の澱粉よりか なり小さく， SEM 観察の結果とあわせて明らかに なった。

2. X 線図形でキヌア澱粉はトウモロコシ，コメ澱粉と 同様に穀類澱粉に代表される A 型図形であった。

3. 電流滴定法によるアミロース含量はキヌア澱粉が 18.7\%，コメが12.7\%，トウモロコシが $27.2 \%$ オすっ た。

4. 糊化特性についてはフォトペーストグラフィー, DSC およびRVAの測定から糊化開始温度がRVAによ る值がいずれの澱粉でも数度高い值を示した。キヌア 澱粉は，ブレークダウンおよびセットバックではコメ， トウモロコシ澱粉のような高い值は認められず，老化 しにくい澱粉であることが示唆された。

\section{謝辞}

本研究を行うにあたり，ご懇切なご指導を賜りました 共立女子大学高橋節子名誉教授, 濱西知子講師, 東京農 業大学矢口行雄教授, 阿久澤さゆり准教授に深く感謝い たします。また，澱粉の粒径分布の測定にご便宜をお与 えくださいました(株)日科機バイオスの斉藤孝雄氏に厚く 御礼申し上げます。

\section{文献}

1 ）小西洋太郎, 不破英二, 森田尚文, 高尾哲也: アマランサ スとキヌア，食の科学，253，30-36，52-58（1999）

2）川井佳子：スポンジケーキの焼成過程に及ぼす糖代替の 
影響.日食工誌，45，357-363（1998）

3 ）小西洋太郎：食品加工総覧，第 9 巻 p 207-209（1999）

4 ）渡辺克美, 伊富貴亜矢, 河村幸雄, 光永俊郎：キノア夕 ンパク質画分の成分組成．日食工誌，50，546（2003）

5 ） 真鍋 久: 嵙穀ブームの背景を探る。日調科誌，38，440 -445 (2005)

6) M. J. Koziol, : Chemical composition and nutritional evaluation of quinoa, J. Food Com. Anal. 5, 35-68 (1992)

7 J. E. Fleming and N. W. Galway: Quinoa, Cereals and Pseudocereals. 3-83 (1995)

$8)$ 大迫早苗：キヌア添加によるスポンジケーキの食味特性. 相模女子大学紀要70B, 15-22 (2006)

9 ）大迫早苗, 永島伸浩：キヌア添加が餅生地の物性ならび に食味特性に及ぼす影響。相模女子大学紀要71B，45-52 (2007)

10）福場博保, 二國二郎監修: 澱粉科学ハンドブック, 朝倉 書店, 東京, p198 (1961)

11）中村道徳 ·貝沼圭二編：澱粉 - 関連糖質実験法，学会出
版センター, 東京, p26-28（1986）

12）中村道徳 - 貝沼圭二編：澱粉 - 関連糖質実験法, 学会出 版センター, 東京, p 73（1986）

13）貝沼圭二, 鈴木繁男, 中村道徳編集 : 澱粉科学実験法, 朝倉書店，東京，p148（1978）

14）福場博保，貝沼圭二：澱粉科学ハンドブック，朝倉書店, 東京, p177（1982）

15）貝沼圭二, 小田恒朗, 鈴木繁男 : 澱粉のリン酸誘導体に 関する研究. 澱粉工誌, 14，24-29（1967）

16) Ranhotra, G, S. et. al: Composition and protein nutritional quality of quinoa. Cereal Chemistry, 70 ( 3 ) : 303-305 (1993)

17）朝岡正子, 高橋慶一, 中平健, 井ノ内直良, 不破英次 : 新形質米乳澱粉の構造特性. 応用糖質科学, 41, 17-23 (1994)

18）不破英次, 小巻利章, 檜作進, 貝沼圭二編：澱粉の科学 の辞典，朝倉書店，東京， p 193-217（2003）

19）庄司一郎, 大西真理子, 小川宣子：米飯のアミログラム による品質評価. 日調科誌，33，212-220（2000） 